\title{
Growth hormone-secreting adenomas: pathology and cell biology
}

\author{
M. Beatriz S. Lopes, M.D., Ph.D. \\ Division of Neuropathology, Department of Pathology, University of Virginia School of Medicine, \\ Charlottesville, Virginia
}

\begin{abstract}
The majority of patients with acromegaly harbor a functioning growth hormone (GH) pituitary adenoma. Growth hormone-secreting adenomas correspond to about $20 \%$ of all pituitary adenomas. From the histopathological point of view, a variety of adenomas may present with clinical signs and symptoms of GH hypersecretion including pure GH cell adenomas (densely and sparsely granulated GH adenomas), mixed GH and prolactin cell adenomas, and monomorphous adenomas with primitive cells able to secrete $\mathrm{GH}$ and prolactin including the acidophilic stem cell adenoma and the mammosomatotroph cell adenoma. In this article, the author reviews the main pathological features of the GH-secreting adenomas and some of the molecular genetics mechanisms involved in their pathogenesis. (DOI: 10.3171/2010.7.FOCUS10169)
\end{abstract}

\author{
KeY Words • pituitary neoplasm \\ animal model
}

\section{- acromegaly $\quad$ molecular genetics •}

$\mathrm{T}$ HE great majority of patients with acromegaly have a pituitary GH-secreting adenoma; ectopic GHRH or GH-secreting neuroendocrine tumors producing acromegaly represent less than $5 \%$ of the patient population. ${ }^{10}$ Growth hormone-secreting adenomas are accompanied by high serum GH and IGF-I levels and signs and symptoms of acromegaly or gigantism. ${ }^{10}$ Overall, these adenomas constitute about $20 \%$ of all pituitary adenomas. ${ }^{27}$ Most patients with acromegaly have macroadenomas when first diagnosed, many of them with suprasellar expansion and parasellar invasion. ${ }^{27}$ Consequently, symptoms due to an expanding tumor mass, including headaches and visual field defects, may also be present in patients with large tumors. In about 30\%-50\% of the patients, cosecretion of PRL with $\mathrm{GH}$ by the tumor results in signs and symptoms of hyperprolactinemia. ${ }^{28,47}$

\section{Pathological Features of GH-Secreting Tumors}

\section{Growth Hormone-Secreting Adenomas}

Pure GH-secreting adenomas are histologically classified into the following 2 variants: the DGGH cell ad-

Abbreviations used in this paper: $\mathrm{CNC}=$ Carney complex; DGGH = densely granulated GH; FIPA = familial isolated pituitary adenoma; $\mathrm{GH}=$ growth hormone; $\mathrm{GHRH}=\mathrm{GH}$ releasing hormone; IGF-I = insulin-like growth factor-I; $\mathrm{LOH}=$ loss of heterozygosity; MEN-1 = multiple endocrine neoplasia Type 1; PRL = prolactin; SGGH = sparsely granulated $\mathrm{GH}$. enoma and the SGGH cell adenoma, reflecting the variable amount of secretory granules present in the cellular cytoplasm (Fig. 1).

The DGGH cell adenomas are composed of large cells with eosinophilic cytoplasm showing considerable granularity, reflecting the great numbers of secretory granules seen at the ultrastructural level (Fig. 2). The nucleus tends to be central and oval with prominent nucleoli. Characteristically, immunohistochemical stains show strong GH positivity dispersed diffusely within the entire tumor. At the ultrastructural level, the DGGH adenomas are composed of cells that resemble the normal somatotrophs of the pituitary gland and are characterized by a well-developed rough endoplasmic reticulum network, prominent Golgi complexes, and numerous large $(300-600 \mathrm{~nm})$ secretory granules. ${ }^{25}$

The SGGH cell adenomas contain cells more chromophobic in appearance than DGGH cell adenomas, and they have eccentric nuclei. The most distinctive feature of these adenomas is the presence of paranuclear eosinophilic structures called fibrous bodies. Immunostaining for $\mathrm{GH}$ is distributed focally within the tumor, and in the cell it can be in a dotlike appearance, reflecting the small amount of secretory granules seen at ultrastructure. In addition, fibrous bodies are strongly positive for cytokeratin (Fig. 3). ${ }^{37}$ Fibrous bodies are characterized at the ultrastructural level by an accumulation of intermediate filaments and tubular smooth-surfaced endoplasmic reticulum (Fig. 3). ${ }^{25}$ 


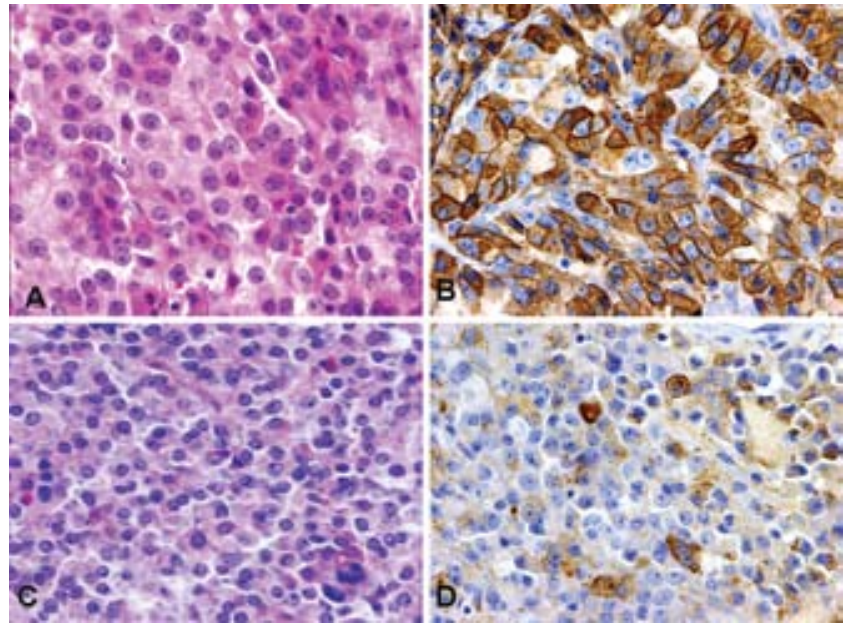

FIG. 1. Photomicrographs of a GH-secreting adenoma. A: A DGGH cell adenoma showing large cells with eosinophilic, granular cytoplasm, and a central nucleus with prominent nucleoli $(\mathrm{H} \& \mathrm{E})$. B: The tumor shows intense and diffuse immunostaining for $\mathrm{GH}$. C: An SGGH cell adenoma is characteristically more chromophobic with $H$ \& $E$ staining. D: Immunohistochemistry for $\mathrm{GH}$ is heterogeneous and less prominent for SGGH cell adenomas than for DGGH cell adenomas. Original magnification $\times 200$.

The distinction of these 2 subtypes of GH cell adenomas is important since these tumors appear to have different clinical behavior. The SGGH cell adenomas exhibit more aggressive biological behavior than the DGGH cell adenomas. ${ }^{28,38,56}$ In a review of almost 90 patients with acromegaly who underwent follow-up at our institution, although no significant difference in cure rate and survival was present between these 2 subtypes of GH-secreting adenomas, SGGH cell adenomas were more likely to be locally invasive than DGGH cell tumors. ${ }^{28}$ Obari et al..$^{38}$ have reported similar findings with a significantly higher incidence of suprasellar extension and cavernous sinus invasion in SGGH than DGGH cell adenomas $(65 \%$ vs $38 \%$, respectively; $\mathrm{p}<0.05)$. Although no significant differences were seen in clinical presentation and GH or IGF-I levels, these authors reported a lower mean patient age at the diagnosis of an SGGH cell adenoma than that of a DGGH cell adenoma ( $43.6 \pm 11.1$ years vs $49.6 \pm 13.8$ years; $\mathrm{p}<0.05) .^{38}$

Additionally, the response of tumors to adjuvant medical treatment appears to differ according to the sub-

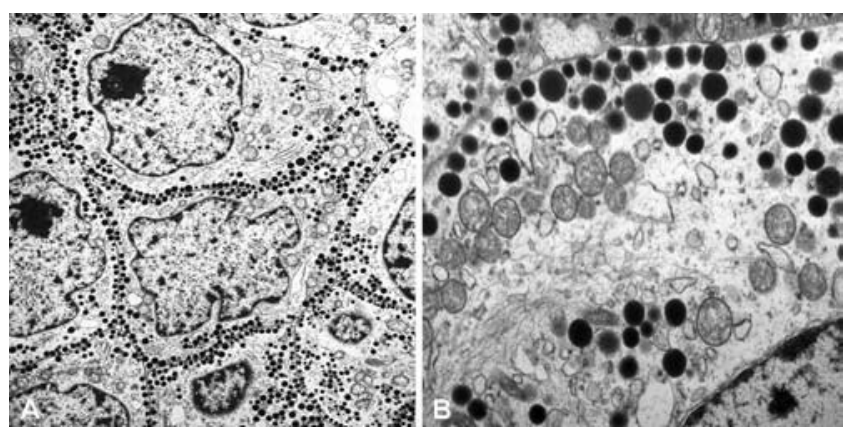

FIG. 2. A DGGH cell adenoma. The ultrastructure exhibits well-developed organelles and abundant large secretory granules. Original magnification $\times 2500$ (A) and $\times 5000$ (B).

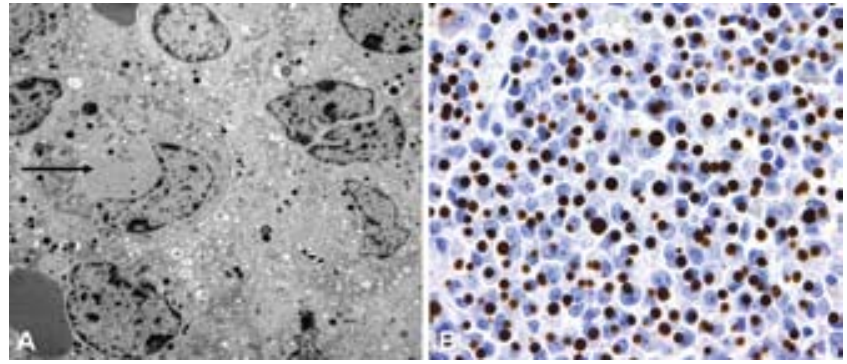

Fig. 3. An SGGH cell adenoma. A: The ultrastructure of SGGH cells display sparse neurosecretory granules and the typical fibrous bodies (arrow). B: Cytokeratin immunostaining highlights fibrous bodies typically seen in these sparsely granulated tumors. Original magnification $\times 2500$ (A) and $\times 200$ (B).

type of GH cell adenoma.7 Tumor subtyping (DGGH) was the strongest predictor of IGF-I normalization in patients with acromegaly receiving postoperative somatostatin analog therapy.

A number of GH-secreting adenomas display secondary immunoreactivity for other pituitary hormones that do not necessarily show clinical or biochemical evidence of hormonal hypersecretion. ${ }^{28,46}$ Secondary immunoreactivity is mostly seen for PRL and for the glycoprotein hormone $\alpha$-subunit; less frequently, immunoreactivity is seen for $\beta-$ follicle-stimulating hormone, $\beta$-luteinizing hormone, and $\beta$-thyroid-stimulating hormone. Apart from the well-characterized mixed GH/PRL-secreting adenomas (see below), plurihormonal differentiation is not clinically symptomatic in the majority of cases.

\section{Mixed GH/PRL-Secreting Adenomas}

A large percentage of $\mathrm{GH}$-secreting adenomas also secrete PRL. About half of the patients with surgically removed GH-secreting adenomas in our institution presented with signs and symptoms of acromegaly and hyperprolactinemia. ${ }^{28}$

Three morphological tumor types that cosecrete GH and PRL can be identified as follows: the mixed GH cell/PRL cell adenoma, the mammosomatotroph cell adenoma, and the acidophilic stem cell adenoma. ${ }^{12,24,26,28,31}$ Mixed GH cell/PRL cell adenomas and mammosomatotroph cell adenomas present clinically with acromegaly and mild hyperprolactinemia; on the other hand, patients with acidophilic stem cell adenoma present with hyperprolactinemia and only rarely with acromegaly. In our experience, these mixed tumors behave more aggressively than any pure GH-secreting adenomas with a lower surgical cure rate. ${ }^{28}$

Mixed GH Cell/PRL Cell Adenoma. These adenomas morphologically resemble GH-secreting adenomas, but immunohistochemistry is demonstrated for both GH and PRL with varying degrees of staining and distribution. The 2 cell types may form small groups or they may be scattered. At the ultrastructural level, these adenomas are bimorphous tumors, consisting of 2 separate cell populations, DGGH or SGGH cells and PRL cells (Fig. 4). ${ }^{12,31}$

Mammosomatotroph Cell Adenoma. This rare GH/ PRL-producing tumor accounts for less than $2 \%$ of all 


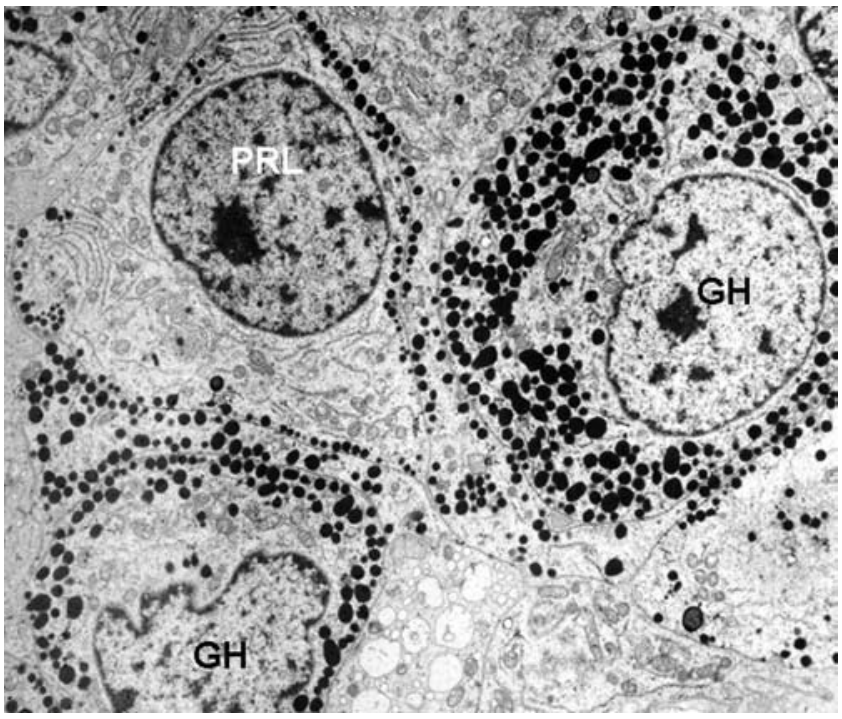

FIG. 4. Mixed GH/PRL cell adenoma. Ultrastructure of a mixed $\mathrm{GH}$ cell/PRL cell-secreting adenoma showing bimorphous cell population with densely granulated $\mathrm{GH}$ cells and PRL cells. Original magnification $\times 2500$.

pituitary adenomas and about $8 \%$ of tumors associated with acromegaly. ${ }^{24}$ Histologically, the adenomas are acidophilic on $\mathrm{H} \& \mathrm{E}$ staining, and immunohistochemical analysis demonstrates the presence of GH and PRL in the cytoplasm of the same tumor cells. These findings have been confirmed by double-labeling studies and by immunoelectron microscopy. ${ }^{24}$ At the ultrastructural level, a monomorphous cell population contains features of $\mathrm{GH}$ and PRL cells. ${ }^{25}$ The cells are mostly similar to DGGH cells, but with irregular secretory granules of variable sizes (200-2000 nm). Granular extrusions and extracellular deposits of secretory material, features consistent with PRL cell differentiation, are characteristically present.

Acidophilic Stem Cell Adenoma. This subtype of mixed adenoma is very rare and represents only the minority of GH/PRL-producing tumors. ${ }^{28,44}$ Unlike the 2 subtypes previously discussed, most of the patients present with symptoms of hyperprolactinemia; acromegaly is uncommon. ${ }^{26}$ The majority of the tumors are rapidly growing macroadenomas with invasive features, a distinct behavior pattern of ordinary prolactinomas; therefore, the diagnosis of such adenomas is of clinical relevance. Histologically, acidophilic stem cell adenomas are chromophobic with focal oncocytic changes of the cytoplasm. Immunoreactivity for PRL and, to a lesser extent, $\mathrm{GH}$ is present in the cytoplasm of the same tumor cells. Electron microscopy is necessary for precise identification of this adenoma. ${ }^{25,26}$ They are composed of a single population of immature cells exhibiting features reminiscent of both SGGH cells and PRL cells. Oncocytic change with the presence giant mitochondria is characteristic of these adenomas.

\section{Growth Hormone-Secreting Pituitary Carcinomas}

Pituitary carcinomas are very rare, comprising less than $1 \%$ of all pituitary neoplasms. ${ }^{32,41,45}$ By definition, pituitary carcinomas are characterized by the presence of either craniospinal dissemination or systemic metastases. ${ }^{45}$
The great majority of reported pituitary carcinomas are hormonally active tumors with endocrine manifestations indistinguishable from those of pituitary adenomas. The most common endocrine syndromes are adrenocorticotropic hormone-secreting tumors with Cushing disease $(42 \%)$ and PRL-secreting tumors presenting with hyperprolactinemia (33\%). ${ }^{45}$ Carcinomas associated with acromegaly or gigantism represent only about $6 \%$ of the reported cases. ${ }^{42}$

The diagnosis of pituitary carcinoma is dependent on the demonstration of metastatic spread. ${ }^{45}$ There are no morphological criteria to distinguish locally aggressive or even markedly atypical adenomas from carcinomas when the tumor is confined to the sella. However, all reported GH carcinomas have presented as highly invasive tumors at the initial presentation. ${ }^{41}$

\section{Medical Treatment and GH-Secreting Adenomas}

Medical therapy is part of the multistep treatment of acromegaly. ${ }^{35}$ Three classes of drugs are mostly available for the treatment of acromegaly including dopamine agonists, somatostatin receptor ligands, and a $\mathrm{GH}$ receptor antagonist. ${ }^{35}$ These drugs may change the morphology of $\mathrm{GH}$-secreting adenomas. Unlike the dramatic effects of dopamine agonists seen in prolactinomas, significant reduction in cell size is uncommonly seen in the GH tumors treated with dopamine agonists and somatostatin receptor ligands. Most frequent changes are characterized by variable degree of perivascular and interstitial fibrosis. ${ }^{21,50} \mathrm{An}$ increase in size of the secretory granules and the presence of larger and heterogeneous lysosomes with takeup of secretory granules (crinophagy) are seen at the ultrastructural level and are believed to be due inhibition of hormone release.

Pathological effects of the $\mathrm{GH}$ receptor antagonist in GH-secreting adenomas are not very well known. This drug does not have a direct antitumor effect. One case report of a $\mathrm{GH}$-secreting adenoma with comparison of pre- and posttreatment effects reported insignificant changes in morphological features. ${ }^{16}$ However, these authors have shown that proliferative markers ( $\mathrm{Ki} 67$ and topoisomerase- $\alpha$ ) were markedly greater in the pegvisomant-exposed tumor than in the earlier specimen. However, there has not been substantiated confirmation of these findings.

\section{Molecular Genetics of GH-secreting Tumors}

Pituitary adenomas appear to result from a multistep and multicausal process in which hereditary genetic disposition, endocrine factors, and specific somatic mutations may serve as contributing factors. Adenomas are mostly monoclonal expansions as demonstrated by X-chromosomal inactivation analysis. ${ }^{11}$ The great majority of adenomas arise in a sporadic manner, and only a minority of adenomas are part of hereditary or familial syndromes. ${ }^{14}$

Familial syndromes in which GH-secreting adenomas arise include the following: 1) MEN-1, linked to somatic mutations of the tumor suppressor gene $M E N-1$ located at the 11 q13 locus; ${ }^{8}$ 2) $\mathrm{CNC}$, linked to mutations of the tumor suppressor gene PRKAR1A located at 17q22$24{ }^{49}$ and less commonly 3 ) McCune-Albright syndrome, 
linked to activating mutation of the $g s p$ oncogene located at $20 \mathrm{q} 13^{55}$ (see below). Growth hormone-secreting adenomas linked to either MEN-1 or CNC are believed to correspond to about $3 \%$ of all GH-secreting tumors. ${ }^{9}$

In addition, a small number of familial pituitary $\mathrm{GH}$-secreting adenomas have been described in the absence of either MEN-1 or CNC. The so-called isolated familial somatotropinoma or FIPA is defined as a clinical syndrome characterized by more than 2 cases of acromegaly or gigantism in a family in the absence of MEN1 or CNC. ${ }^{3}$ FIPAs are believed to correspond to about $1 \%$ of all GH-secreting adenomas. ${ }^{9}$ In several groups of the FIPAs, an association with LOH at the $11 \mathrm{q} 13$ locus unrelated to the $M E N-1$ gene has been demonstrated. ${ }^{5}$ Recently, a germline mutation of the aryl hydrocarbon receptor-interacting protein $(A I P)$ gene has been reported in a set of Finnish and Italian families with pituitary adenoma predisposition. ${ }^{54}$ The AIP gene is located at 11q13, the same region as the $M E N 1$ gene. Tumor samples from affected individuals showed LOH at the AIP locus, suggesting that $A I P$ acts as a tumor suppressor gene. In the remaining FIPAs there has not been yet characterization of a single genetic alteration. In the overall group, however, there is a description of mutations of the AIP gene in about $15 \%$ of families. ${ }^{13}$ Thus far, 3 sites of mutations of the $A I P$ gene have been identified in this group of familial somatotrofinomas. ${ }^{39}$ Mutations of the AIP gene were also found in a small number of patients with sporadic pituitary adenomas, mostly GH-secreting tumors. ${ }^{39}$

The majority of GH-secreting adenomas are, how- ever, sporadic tumors in which the primary genetic defect remains unknown. A number of oncogenes and tumor suppressor genes have been recognized as potential participants in tumorigenesis of pituitary adenomas including GH-secreting adenomas. ${ }^{17}$ As previously discussed, in patients with MEN-1, LOH of 11q13 is present in pituitary adenomas and in other lesions commonly seen in the syndrome, including parathyroid hyperplasia and tumors of the endocrine pancreas. ${ }^{8}$ However, the $M E N-1$ gene has not been proven to be a major player in sporadic GH-secreting adenomas. ${ }^{4}$

The most commonly found genetic alteration in sporadic $\mathrm{GH}$-secreting adenomas is the activating mutation of the $g s p$ gene. ${ }^{29,30,52}$ The $g s p$ oncogene mutation corresponds to a point mutation of the $\alpha$-subunit of the stimulatory G-protein (GNAS), a stimulatory protein of adenylyl cyclase at the membrane level. ${ }^{29,30,33}$ The GNAS protein is coupled to the GHRH receptor, a G protein-coupled receptor located at the cell membrane of somatotrophs, that mediates GH transcription by inducing cyclic adenosine monophosphate via a cyclic adenosine monophosphate response element-binding protein (CREB). The mutated GNAS protein inhibits GTPase activity, maintaining the adenylyl cyclase system in a continuously turned-on state, therefore mimicking the effects of GHRH on hormone signaling. The $g s p$ gene mutation has been identified in about $40 \%$ of GH-secreting adenomas in Caucasians and in lower frequency in Asians. ${ }^{33,48}$ Recently, gsp gene mutation has been reported in about $10 \%$ of tumors of patients with sporadic acromegaly in Brazil. ${ }^{51}$

TABLE 1: Genetic alterations implicated in GH-secreting adenomas

\begin{tabular}{|c|c|}
\hline Alteration & Associated Disorder \\
\hline Gene & Inherited or Familial Tumor \\
\hline Menin (11q13) & MEN-1 \\
\hline PRKR1A (17q22-24) & $\mathrm{CNC}$ \\
\hline gsp (20q13.3) & McCune-Albright syndrome \\
\hline \multirow[t]{2}{*}{ AIP (11q13) } & FIPA \\
\hline & Sporadic Tumor \\
\hline gsp (20q13.3) & mostly in DGGH cell adenomas ( $10 \%-40 \%$ of cases) \\
\hline CREB (2q32.3-q34) & cAMP response element-binding protein, transcription factor, constitutive phosphorylation† \\
\hline $\begin{array}{l}\text { Oncogene/Tumor Suppressor } \\
\text { Gene }\end{array}$ & Result \\
\hline PTTG (5q22)* & pituitary tumor-transforming protein, securin protein, overexpression $\ddagger$ \\
\hline GADD45G (9q22.1-q22.2)* & growth arrest \& DNA damage-inducible $45 y$, proapoptotic factor, epigenetic silencing§ \\
\hline ODC1 $(2 p 25)^{*}$ & ornithine decarboxylase-1, overexpression $\mathbb{1}$ \\
\hline BAG1 (9p12)* & Bcl-2-associated athanogene, overexpression ${ }^{* *}$ \\
\hline CDKN2C (1p32)* & cyclin-dependent kinase inhibitor $2 \mathrm{C}(\mathrm{p} 18)$, underexpression ${ }^{\star *}$ \\
\hline WIF1 (12)* & Wnt inhibitory factor-1, underexpression†† \\
\hline $\begin{array}{l}\text { * Genetic alterations not specific to } \\
\dagger \text { According to Bertherat et al. } \\
\ddagger \text { According to Pei and Melmed. } \\
\S \text { According to Zhang et al. } \\
\text { † According to Evans et al. } \\
\text { ** According to Morris et al. } \\
\text { †† According to Elston et al. }\end{array}$ & H-secreting adenomas. \\
\hline
\end{tabular}




\section{Pathology of GH-secreting tumors}

TABLE 2: Animal models for GH-secreting adenomas in the literature*

\begin{tabular}{llll}
\hline \multicolumn{1}{c}{ Authors \& Year } & \multicolumn{1}{c}{ Gene } & Model & \multicolumn{1}{c}{ Pituitary Lesion } \\
\hline Asa et al., 1992, \& Mayo et al., 1988 & GHRH & transgenic & mammosomatotroph hyperplasia \& adenoma \\
Fedele et al., 2002 & HMGA2 & transgenic & mixed GH/PRL adenoma \\
Fedele et al., 2005 & HMGA1 & transgenic & mixed GH/PRL adenoma \\
Abbud et al., 2005 & aGSU.PTTG & transgenic & plurihormonal hyperplasia \& occasional microadenoma (including GH) \\
Donangelo et al., 2006 & aGSU.PTTGxRb+/- & bitransgenic & plurihormonal hyperplasia, higher incidence of adenomas (including GH), \& \\
& & & intermediate lobe ACTH tumors \\
Egashira et al., 2008 & Prop1 & transgenic & GH, PRL, TSH, \&/or gonadotrophin-adenomas \\
\hline
\end{tabular}

* $\mathrm{ACTH}=$ adrenocorticotropic hormone; $\mathrm{TSH}=$ thyroid stimulating hormone.

The presence of $g s p$ mutation in a GH cell adenoma does not appear to correlate with patient's age, sex, tumor size, or circulating GH levels. ${ }^{48}$ However, patients appear to have higher circulating levels of $\alpha$-subunit of glycoproteins. Moreover, gsp-mutated adenomas have better response to somatostatin analogs drugs. Growth hormonesecreting tumors with $g s p$ mutations, although indistinct from tumors without $g s p$ mutations from a morphological point of view, are typically DGGH cell adenomas. ${ }^{48}$

Unlike DGGH cell adenomas that most likely exhibit the gsp gene mutation as mentioned previously, SGGH cell adenomas have been demonstrated by some as having preferentially a somatic histidine-to-leucine substitution in codon 49 of the extracellular domain of the GH receptor. ${ }^{2}$ This genetic dissimilarity may explain the low response of SGGH cell adenomas to somatostatin analog drugs. ${ }^{2}$

The $g s p$ oncogene mutation is very rare in other pituitary tumor subtypes, occurring in only $10 \%$ of clinically nonfunctioning pituitary adenomas and in 5\% of corticotroph adenomas. ${ }^{48}$ As mentioned previously, activating mutation of $g s p$ represents the basis of the McCune-Albright syndrome, which is characterized by somatotroph hyperplasia and polyostotic fibrous dysplasia of the bones. ${ }^{55}$

Since mutational events are rare in GH-secreting adenomas, the identification of other candidate genes of significance in the adenoma tumorigenesis has been intensively explored. Several studies have used microarraybased, high-throughput gene profiling for identification of candidate genes and pituitary-specific signaling pathways that may be participate in pituitary tumorigenesis, including studies analyzing $\mathrm{GH}$-secreting adenomas. ${ }^{19,20,36,43} \mathrm{Ex}$ cept for genes linked to adenoma subtype, including $G H$ and $G H R H-R,{ }^{36,43}$ the majority of identified genes with potential tumorigenic effect are not unique to GH-secreting adenomas and seem to contribute to the pathogenesis of most adenomas (Table 1).

\section{Animal Models for GH-Secreting Pituitary Tumorigenesis}

Several animal models have been developed for the understanding of pituitary tumorigenesis by overexpressing oncogenes or knocking out tumor suppressor genes known to play a role in human disease. However, these animal models do not completely recapitulate pituitary human tumorigenesis because animal tumor formation is frequently preceded by hyperplasia, an unlikely event in human pituitary tumor formation. Animal models resulting in GH-secreting adenomas have been well characterized since the late 1980 s, particularly with the description of the transgenic mouse for human $\mathrm{GHRH}^{34}$ that, under extended exposure to GHRH, leads to mammosomatotroph hyperplasia and adenoma formation. ${ }^{3}$ Table 2 shows some of the current animal models that develop GH hyperplasia and/or tumors.

\section{Disclosure}

The author reports no conflict of interest concerning the materials or methods used in this study or the findings specified in this paper.

\section{References}

1. Abbud RA, Takumi I, Barker EM, Ren SG, Chen DY, Wawrowsky K, et al: Early multipotential pituitary focal hyperplasia in the $\alpha$-subunit of glycoprotein hormone-driven pituitary tumor-transforming gene transgenic mice. Mol Endocrinol 19:1383-1391, 2005

2. Asa SL, Digiovanni R, Jiang J, Ward ML, Loesch K, Yamada S, et al: A growth hormone receptor mutation impairs growth hormone autofeedback signaling in pituitary tumors. Cancer Res 67:7505-7511, 2007

3. Asa SL, Kovacs K, Stefaneanu L, Horvath E, Billestrup N, Gonzalez-Manchon C, et al: Pituitary adenomas in mice transgenic for growth hormone-releasing hormone. Endocrinology 131:2083-2089, 1992

4. Bale AE, Norton JA, Wong EL, Fryburg JS, Maton PN, Oldfield $\mathrm{EH}$, et al: Allelic loss on chromosome 11 in hereditary and sporadic tumors related to familial multiple endocrine neoplasia type 1. Cancer Res 51:1154-1157, 1991

5. Beckers A, Daly AF: The clinical, pathological, and genetic features of familial isolated pituitary adenomas. Eur J Endocrinol 157:371-382, 2007

6. Bertherat J, Chanson P, Montminy M: The cyclic adenosine 3',5'-monophosphate-responsive factor CREB is constitutively activated in human somatotroph adenomas. Mol Endocrinol 9:777-783, 1995

7. Bhayana S, Booth GL, Asa SL, Kovacs K, Ezzat S: The implication of somatotroph adenoma phenotype to somatostatin analog responsiveness in acromegaly. J Clin Endocrinol Metab 90:6290-6295, 2005

8. Byström C, Larsson C, Blomberg C, Sandelin K, Falkmer U, Skogseid B, et al: Localization of the MEN1 gene to a small region within chromosome 11q13 by deletion mapping in tumors. Proc Natl Acad Sci U S A 87:1968-1972, 1990

9. Cazabat L, Guillaud-Bataille M, Bertherat J, Raffin-Sanson ML: Mutations of the gene for the aryl hydrocarbon receptorinteracting protein in pituitary adenomas. Horm Res 71:132141,2009 
10. Chanson P, Salenave S, Kamenicky P, Cazabat L, Young J: Pituitary tumours: acromegaly. Best Pract Res Clin Endocrinol Metab 23:555-574, 2009

11. Clayton RN, Farrell WE: Pituitary tumour clonality revisited. Front Horm Res 32:186-204, 2004

12. Corenblum B, Sirek AM, Horvath E, Kovacs K, Ezrin C: Human mixed somatotrophic and lactotrophic pituitary adenomas. J Clin Endocrinol Metab 42:857-863, 1976

13. Daly AF, Vanbellinghen JF, Khoo SK, Jaffrain-Rea ML, Naves LA, Guitelman MA, et al: Aryl hydrocarbon receptorinteracting protein gene mutations in familial isolated pituitary adenomas: analysis in 73 families. J Clin Endocrinol Metab 92:1891-1896, 2007

14. Daly AF, Tichomirowa MA, Beckers A: Genetic, molecular and clinical features of familial isolated pituitary adenomas. Horm Res 71 (Suppl 2):116-122, 2009

15. Donangelo I, Gutman S, Horvath E, Kovacs K, Wawrowsky $\mathrm{K}$, Mount M, et al: Pituitary tumor transforming gene overexpression facilitates pituitary tumor development. Endocrinology 147:4781-4791, 2006

16. Drake WM, Berney DM, Kovacs K, Monson JP: Markers of cell proliferation in a GH-producing adenoma of a patient treated with pegvisomant. Eur J Endocrinol 153:203-205, 2005

17. Dworakowska D, Grossman AB: The pathophysiology of pituitary adenomas. Best Pract Res Clin Endocrinol Metab 23: 525-541, 2009

18. Egashira N, Minematsu T, Miyai S, Takekoshi S, Camper SA, Osamura RY: Pituitary changes in Propl transgenic mice: hormone producing tumors and signet-ring type gonadotropes. Acta Histochem Cytochem 41:47-57, 2008

19. Elston MS, Gill AJ, Conaglen JV, Clarkson A, Shaw JM, Law AJ, et al: Wnt pathway inhibitors are strongly down-regulated in pituitary tumors. Endocrinology 149:1235-1242, 2008

20. Evans CO, Young AN, Brown MR, Brat DJ,Parks JS, Neish AS, et al: Novel patterns of gene expression in pituitary adenomas identified by complementary deoxyribonucleic acid microarrays and quantitative reverse transcription-polymerase chain reaction. J Clin Endocrinol Metab 86:3097-3107, 2001

21. Ezzat S, Horvath E, Harris AG, Kovacs K: Morphological effects of octreotide on growth hormone-producing pituitary adenomas. J Clin Endocrinol Metab 79:113-118, 1994

22. Fedele M, Battista S, Kenyon L, Baldassarre G, Fidanza V, Klein-Szanto AJP, et al: Overexpression of the HMGA2 gene in transgenic mice leads to the onset of pituitary adenomas. Oncogene 21:3190-3198, 2002

23. Fedele M, Pentimalli F, Baldassarre G, Battista S, Klein-Szanto AJP, Kenyon L, et al: Transgenic mice overexpressing the wild-type form of the HMGAl gene develop mixed growth hormone/prolactin cell pituitary adenomas and natural killer cell lymphomas. Oncogene 24:3427-3435, 2005

24. Felix IA, Horvath E, Kovacs K, Smyth HS, Killinger DW, Vale J: Mammosomatotroph adenoma of the pituitary associated with gigantism and hyperprolactinemia. A morphological study including immunoelectron microscopy. Acta Neuropathol 71:76-82, 1986

25. Horvath E, Kovács K: The adenohypophysis, in Kovács K, Asa SL (eds): Functional Endocrine Pathology. Boston: Blackwell Scientific, 1991, pp 245-281

26. Horvath E, Kovacs K, Singer W, Smyth HS, Killinger DW, Erzin C, et al: Acidophil stem cell adenoma of the human pituitary: clinicopathologic analysis of 15 cases. Cancer 47: 761-771, 1981

27. Kontogeorgos G, Watson RE Jr, Lindell EP, Barkan AL, Farrell WE, Lloyd RV: Growth hormone producing adenoma, in DeLellis RA, Lloyd RV, Heitz PU, et al (eds): World Health Organization Classification of Tumours. Pathology and Genetics: Tumours of Endocrine Organs. Lyon: IARC Press, 2004, pp 14-19

28. Kreutzer J, Vance ML, Lopes MBS, Laws ER Jr: Surgical management of GH-secreting pituitary adenomas: an outcome study using modern remission criteria. J Clin Endocrinol Metab 86:4072-4077, 2001

29. Landis CA, Harsh G, Lyons J, Davis RL, McCormick F, Bourne HR: Clinical characteristics of acromegalic patients whose pituitary tumors contain mutant Gs protein. J Clin Endocrinol Metab 71:1416-1420, 1990

30. Landis CA, Masters SB, Spada A, Pace AM, Bourne HR, Vallar L: GTPase inhibiting mutations activate the alpha chain of Gs and stimulate adenylyl cyclase in human pituitary tumours. Nature 340:692-696, 1989

31. Lloyd RV, Gikas PW, Chandler WF: Prolactin and growth hormone-producing pituitary adenomas. An immunohistochemical and ultrastructural study. Am J Surg Pathol 7:251-260, 1983

32. Lopes MBS, Scheithauer BW, Schiff D: Pituitary carcinoma: diagnosis and treatment. Endocrine 28:115-121, 2005

33. Mantovani G, Lania AG, Spada A: GNAS imprinting and pituitary tumors. Mol Cell Endocrinol 326:15-18, 2010

34. Mayo KE, Hammer RE, Swanson LW, Brinster RL, Rosenfeld MG, Evans RM: Dramatic pituitary hyperplasia in transgenic mice expressing a human growth hormone-releasing factor gene. Mol Endocrinol 2:606-612, 1988

35. Melmed S, Colao A, Barkan A, Molitch M, Grossman AB, Kleinberg D, et al: Guidelines for acromegaly management: an update. J Clin Endocrinol Metab 94:1509-1517, 2009

36. Morris DG, Musat M, Czirják S, Hanzély Z, Lillington DM, Korbonits M, et al: Differential gene expression in pituitary adenomas by oligonucleotide array analysis. Eur J Endocrinol 153:143-151, 2005

37. Neumann PE, Goldman JE, Horoupian DS, Hess MA: Fibrous bodies in growth hormone-secreting adenomas contain cytokeratin filaments. Arch Pathol Lab Med 109:505-508, 1985

38. Obari A, Sano T, Ohyama K, Kudo E, Qian ZR, Yoneda A, et al: Clinicopathological features of growth hormone-producing pituitary adenomas: difference among various types defined by cytokeratin distribution pattern including a transitional form. Endocr Pathol 19:82-91, 2008

39. Ozfirat Z, Korbonits M: AIP gene and familial isolated pituitary adenomas. Mol Cell Endocrinol 326:71-79, 2010

40. Pei L, Melmed S: Isolation and characterization of a pituitary tumor-transforming gene (PTTG). Mol Endocrinol 11:433441, 1997

41. Pernicone PJ, Scheithauer BW, Sebo TJ, Kovacs KT, Horvath E, Young WF Jr, et al: Pituitary carcinoma: a clinicopathologic study of 15 cases. Cancer 79:804-812, 1997

42. Ragel BT, Couldwell WT: Pituitary carcinoma: a review of the literature. Neurosurg Focus 16(4):E7, 2004

43. Ruebel KH, Leontovich AA, Jin L, Stilling GA, Zhang H, Qian X, et al: Patterns of gene expression in pituitary carcinomas and adenomas analyzed by high-density oligonucleotide arrays, reverse transcriptase-quantitative PCR, and protein expression. Endocrine 29:435-444, 2006

44. Saeger W, Lüdecke DK, Buchfelder M, Fahlbusch R, Quabbe HJ, Petersenn S: Pathohistological classification of pituitary tumors: 10 years of experience with the German Pituitary Tumor Registry. Eur J Endocrinol 156:203-216, 2007

45. Scheithauer BW, Kovacs K, Horvath E, Roncaroli F, Ezzat S, Asa SL, et al: Pituitary carcinoma, in DeLellis RA, Lloyd RV, Heitz PU, et al (eds): World Health Organization Classification of Tumours. Pathology and Genetics: Tumours of Endocrine Organs. Lyon: IARC Press, 2004, pp 36-39

46. Scheithauer BW, Kovacs K, Randall RV, Horvath E, Laws ER Jr: Pathology of excessive production of growth hormone. Clin Endocrinol Metab 15:655-681, 1986

47. Shimon I, Melmed S: Acromegaly: differential diagnosis and treatment, in Wierman ME (ed): Contemporary Endocrinology. Diseases of the Pituitary: Diagnosis and Treatment. Totowa, NJ: Humana Press, 1997, pp 135-152 


\section{Pathology of GH-secreting tumors}

48. Spada A, Arosio M, Bochicchio D, Bazzoni N, Vallar L, Bassetti M, et al: Clinical, biochemical, and morphological correlates in patients bearing growth hormone-secreting pituitary tumors with or without constitutively active adenylyl cyclase. J Clin Endocrinol Metab 71:1421-1426, 1990

49. Stergiopoulos SG, Abu-Asab MS, Tsokos M, Stratakis CA: Pituitary pathology in Carney complex patients. Pituitary 7: 73-82, 2004

50. Stevenaert A, Harris AG, Kovacs K, Beckers A: Presurgical octreotide treatment in acromegaly. Metabolism 41 (9 Suppl 2): 51-58, 1992

51. Taboada GF, Tabet AL, Naves LA, de Carvalho DP, Gadelha MR: Prevalence of gsp oncogene in somatotropinomas and clinically non-functioning pituitary adenomas: our experience. Pituitary 12:165-169, 2009

52. Vallar L, Spada A, Giannattasio G: Altered Gs and adenylate cyclase activity in human GH-secreting pituitary adenomas. Nature 330:566-568, 1987

53. Verloes A, Stevenaert A, Teh BT, Petrossians P, Beckers A: Familial acromegaly: case report and review of the literature. Pituitary 1:273-277, 1999

54. Vierimaa O, Georgitsi M, Lehtonen R, Vahteristo P, Kokko A, Raitila A, et al: Pituitary adenoma predisposition caused by germline mutations in the AIP gene. Science 312:1228-1230, 2006

55. Weinstein LS, Yu S, Warner DR, Liu J: Endocrine manifestations of stimulatory $\mathrm{G}$ protein alpha-subunit mutations and the role of genomic imprinting. Endocr Rev 22:675-705, 2001

56. Yamada S, Aiba T, Sano T, Kovacs K, Shishiba Y, Sawano S, et al: Growth hormone-producing pituitary adenomas: correlations between clinical characteristics and morphology. Neurosurgery 33:20-27, 1993

57. Zhang X, Sun H, Danila DC, Johnson SR, Zhou Y, Swearingen $\mathrm{B}$, et al: Loss of expression of GADD45 gamma, a growth inhibitory gene, in human pituitary adenomas: implications for tumorigenesis. J Clin Endocrinol Metab 87:1262-1267, 2002

Manuscript submitted June 15, 2010.

Accepted July 26, 2010.

Address correspondence to: M. Beatriz S. Lopes, M.D., Ph.D, Department of Pathology, University of Virginia School of Medicine, 1215 Lee Street, HEP-Room 3060, Charlottesville, Virginia 229080214, email:msl2e@virginia.edu. 